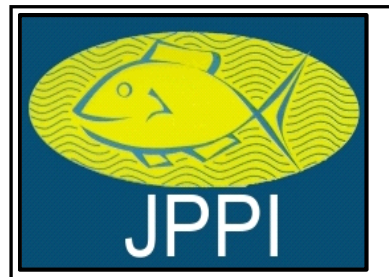

Tersedia online di: http://ejournal-balitbang.kkp.go.id/index.php/jppi

e-mail:jppi.puslitbangkan@gmail.com

JURNAL PENELITIANPERIKANANINDONESIA

Volume 23 Nomor 1 Maret 2017

p-ISSN: 0853-5884

e-ISSN: 2502-6542

Nomor Akreditasi: 653/AU3/P2MI-LIPI/07/2015

\title{
APLIKASI MODEL SURPLUS PRODUKSI NON-EKUILIBRIUM PADA PERIKANAN LAYANG ( Decapterus macrosoma) DI LAUT JAWA
}

\section{APPLICATION OF NON-EQUILIBRIUM SURPLUS PRODUCTION MODEL ON SCADS ( Decapterus macrosoma) FISHERY IN JAVA SEA}

\author{
Suherman Banon Atmadja ${ }^{\star 1}$, Bambang Sadhotomo ${ }^{1}$ dan Duto Nugroho ${ }^{2}$ \\ ${ }^{1}$ Balai Penelitian Perikanan Laut, Komplek Pelabuhan Perikanan Samudera, Komp. Pelabuhan Nizam Zachman, \\ Jl. Muara Baru Ujung, Jakarta Utara-14430, Indonesia \\ ${ }^{2}$ Pusat Penelitian dan Pengembangan Perikanan, Jl. Pasir Putih II, Ancol Timur, Jakarta Utara-14430, Indonesia \\ Teregistrasi I tanggal: 24 Nopember 2016; Diterima setelah perbaikan tanggal: 23 Maret 2017; \\ Disetujui terbit tanggal: 22 April 2017
}

\begin{abstract}
ABSTRAK
Ikan layang (Decapterus macrosoma) dikelompokkan sebagai ikan pelagis yang menyukai habitat oseanik. Kajian ini membahas pendugaan biomassa dengan pendekatan model surplus produksi (MSY) pada spesies layang berdasarkan himpunan data runtut CPUE dan produksi perikanan pukat cincin yang berasal dari Pekalongan dan Juwana selama kurun waktu 19762009. Analisis menggunakan pendekatan non-ekuilibrium dengan bantuan perangkat aplikasi ASPIC 7. Hasil penelitian menunjukan sejak tahun 1991 sampai dengan 2005, status biomassa cenderung terus menurun dan tingkat eksploitasi telah melampaui ambang batas untuk menentukan pengelolaan dengan besaran keseimbangan Fmsy dan Bmsy =1. Sejak 2006, penurunan secara drastis baik jumlah armada pukat cincin maupun aktivitas penangkapannya telah memberikan peluang terhadap pemulihan stok menuju tingkat biomassa optimal. Keterbatasan kemampuan pengendalian terhadap dinamika perikanan berakibat pada peningkatan upaya penangkapan, perubahan kapasitas maupun taktik penangkapan. Pergeseran teknologi tersebut cenderung lebih rasional untuk peningkatan produktivitas dan abai terhadap tingkat mortalitas penangkapan yang sedang berjalan $\left(F_{t}\right)$. Untuk itu, upaya pengendalian yang lebih konservatif tentang risiko terhadap pembiaran pola eksploitasi yang sedang berjalan sangat diperlukan. Evaluasi terhadap jumlah armada aktif merupakan landasan untuk mendapatkan status pemanfaatan yang sedang berjalan dan penutupan izin masuknya armada baru merupakan tindakan pengelolaan patut dilakukan untuk memperbesar peluang pemulihan stok pada tingkat optimal.
\end{abstract}

Kata Kunci: Surplus produksi; non-equilibrium; ikan layang; Laut Jawa

\begin{abstract}
The scads (Decapterus macrosoma) were grouped into pelagic fish associated with oceanic habitat. This study deal with the estimation of biomass and MSY of shortfin scads base on CPUE and production of purse seiners fishery in Pekalongan and Juwana during 1976-2009. Analysis was carried out using non-equilibrium approach through programs package of ASPIC 7. The results showed that since 1991 to 2005, the trend of biomass continued to decline and exploitation rates exceed management benchmarks i.e. Fmsy and Bmsy = 1. Since 2006, drastic decline in number of purse seine and their activity indicates that the probability of recovery biomass to optimum level were increased. However, due to limited capacity on managing the dynamics of fishing activity under the scheme of productivity and ignoring the increasing fishing mortality $\left(F_{t}\right)$, the biomass tends to decline. Therefore, revisiting the fisheries system on input control should be more
\end{abstract}


rational to maintain fishing mortality at equal to Fmsy. A conservative approach on restrictive licencing for new entrance would be necessary to increase the probability of rebuilding the pelagic fish stock at optimal level.

\section{Keywords: Surplus production; non-equilibrium; Scads; Java Sea}

\section{PENDAHULUAN}

Terdapat dua jenis ikan layang tertangkap di perairan Laut Jawa, yaitu Decapterus macrosoma dan Decapterus russeli. Kontribusi spesies Ikan layang deles (Decapterus macrosoma) mencapai rat-rata $25 \%$ dari total hasil tangkapan pukat cincin, dengan komposisi ukuran yang terdiri dari ikan muda (umur $<1$ tahun) dan terkategori belum aktif berreproduksi. Kelompok ikan muda ini memasuki Laut Jawa mengikuti pergeseran massa air bersalinitas lebih tinggi yang datang dari Timur (Laut Flores) dan Timur laut (Selat Makassar). Struktur ukuran ikan hasil tangkapan berada pada kisaran antara 12-18 (cmFL) mendominasi (> 90\%) hasil tangkapan (Atmadja 2008; Atmadja \& Sadhotomo 1985). Pengamatan terhadap sebaran ukuran panjang tahunan menunjukkan bahwa rata-rata ukuran ikan yang tertangkap relatif pada kisaran umur yang tidak berubah (Atmadja, 2008). Terjadinya peningkatan produksi pukat cincin yang didaratkan di Pekalongan dan Juwana sangat terkait dengan perluasan operasi penangkapan ke bagian timur Laut Jawa dan hingga Selat Makassar pada akhir 1985 (Atmadja, 1999). Perkembangan taktik dan strategi pemanfaatan melalui investasi kapal baru dengan ukuran bobot kapal lebih dari 100 GT yang diikuti peningkatan efisiensi penangkapan melalui penggunaan lampu sorot (cahaya) sebagai alat bantu pengumpul ikan memberikan konsekuensi logis terhadap peningkatan produktivitas armada pukat cincin di kedua lokasi pendaratan utama tersebut (Atmadja \& Sadhotomo, 1985; Atmadja, 2008).

Observasi terhadap pemanenan ikan pelagis kecil dengan pukat cincin sebelum terjadinya ekspansi daerah penangkapan ikan layang ( $D$. russelli) ke luar laut Jawa, memperlihatkan bahwa hasil pendaratan kedua jenis ikan layang $(D$. russelli dan $D$. macrosoma) memberikan proporsi terbesar (> 70\%) dari hasil tangkapan (Atmadja, 1999; Potier \& Sadhotomo, 1995; Potier, 1998). Tidak terkendalinya penggunaan teknologi untuk mendukung upaya pemanfaatan sumber daya ikan pelagis kecil menyebabkan terjadinya peningkatan mortalitas penangkapan. Tingginya mortalitas penangkapan yang didominasi ikan berumur muda menyebabkan rendahnya sediaan biomassa induk yang berakibat pada hasil tangkapan terus menurun. Estimasi besarnya biomassa pada 2005 menurun secara nyata hingga kurang dari 25\% dari biomassa awal 1990 (Atmadja, 2008). Fenomena ini, sejalan dengan analisis stok kelompok pelagis kecil pada kurun waktu tersebut, memberikan estimasi sediaan biomassa ikan layang hanya tersisa kurang dari $25 \%$ (Nugroho, 2006; Atmadja, 2008; Cardinale et al., 2009).

Penggunaan model surplus produksi klasik pada kajian stok dilakukan dengan asumsi bahwa status sumber daya pada kondisi seimbang, namun stok ikan umumnya berada pada kondisi tidak stabil atau kondisi non - ekuilibrium. Ketidak stabilan tersebut merupakan karakteristik populasi yang berusaha bersifat adaptif terhadap perubahan kematian alami yang disebabkan oleh fluktuasi dan perubahan lingkungan sekitarnya (Hilborn \& Walters, 1992). Salah satu upaya untuk mendekati ketidak stabilan tersebut, Prager (1994) mengembangkan pendekatan perubahan biomassa pada kurun waktu pemanfaatan yang relatif panjang dengan asumsi biomassa nonekuilibrium melalui penggunaan program aplikasi ASPIC (a surplus production model incorporating covariates). Pendekatan ini dianggap sebagai upaya perbaikan dari pendekatan yang memungkinkan para ilmuwan untuk melacak dan mendeteksi berbagai tingkat biomassa dan eksploitasi berdasarkan dinamika perikanan pada kurun waktu tertentu. Namun demikian, Quetglas et al. (2013) menyatakan bahwa peran faktor lingkungan dan tekanan pemanfaatan sangat mempengaruhi dinamika populasi ikan yang dimanfaatkan. Sedangkan Botsford et al. (2014) menyatakan bahwa terjadinya fluktuasi kelimpahan populasi pada suatu perikanan belum sepenuhnya dipahami dan masih memerlukan data lingkungan runtut waktu yang bersifat dekadal.

Penelitian ini bertujuan untuk mengetahui secara keseluruhan perubahan status stok ikan layang pada kurun waktu pemanfaatan 1976 - 2009 berdasarkan model surplus produksi non-ekuilibrium. Hasil analisis ini diharapkan dapat mempertegas hasil dan kesimpulan penelitan sebelumnya tentang status stok dan pengendalian mortalitas penangkapan armada pukat cincin yang beroperasi di Laut Jawa. 


\section{BAHAN DAN METODE Pengambilan Data}

Sumber data berasal dari data tahunan tentang upaya penangkapan dan produksi ikan layang deles $(D$. macrosoma) hasil tangkapan kapal pukat cincin komersial yang berpangkalan di Pekalongan dan Juwana, selama kurun waktu 1976-2009. Proporsi ikan layang (Decapterus russellii dan D. macrosoama) diterminasi berdasarkan hasil penelitian sebelumnya (Potier, 1998; Nugroho, 2006; Atmadja, 2008). Sementara produksi tahunan ikan layang (Decapterus spp.) di Laut Jawa diperoleh dari data statistk perikanan Indonesia selama kurun waktu 1980-2009 (DJP, 1980-2000; DJPT, 2001-2010). Estimasi CPUE ikan layang dihitung dari perikanan pukat cincin Pekalongan dan Juwana pada kurun waktu tersebut.

\section{Analisis Data}

Model produksi (Schaefer, 1954; 1957) mengasumsikan pertumbuhan populasi mengikuti pola logistik, di mana perubahan biomassa stok dari waktu ke waktu $(d \mathrm{Bt} / d \mathrm{t})$ merupakan fungsi kuadrat dari biomassa dan disusun dalam persamaan:

$$
\frac{d B}{d t}=r B_{t}-\left(\frac{r}{K}\right) B_{t}^{2}
$$

Dimana $r$ adalah tingkat pertumbuhan intrinsik populasi, dan $\mathrm{K}$ adalah daya dukung lingkungan.

Hasil tangkapan dari populasi (C) akan berpengaruh terhadap perubahan biomassa:

$$
\frac{d B_{t}}{d t}=\left(r B_{t}-\left(\frac{r}{K}\right) B_{t}^{2}\right)-C
$$

Non-ekuilibrium model surplus produksi yang menggabungkan kovariat (ASPIC) merupakan sebuah program komputasi yang dibangun berdasarkan pada asumsi non-ekuilibrium dari stok ikan, dan menggabungkan nilai kovariat dari parameter terhitung. Model surplus produksi yang diadopsi adalah versi waktu kontinu dari model Graham-Schaefer (Prager, 1994). Hasil tangkapan (persamaan 2) berasumsi bahwa CPUE sebanding dengan kelimpahan (CPUE $=q B$ ) atau $\mathrm{C}=\mathrm{qEB}$ atau $\mathrm{C}=\mathrm{FB}$, maka model produksi versi waktu kontinu dari model Graham-Schaefer tersebut menjadi:

$$
\frac{d B t}{d t}=\left(r-F_{t}\right) B_{t}-\frac{r}{K} B_{t}^{2}
$$

dimana,

$$
\begin{aligned}
& \mathrm{C}=\text { hasil tangkapan } \\
& \mathrm{q}=\text { koefisien kemampuan tangkap },
\end{aligned}
$$

$$
\begin{aligned}
& \mathrm{E}=\text { upaya penangkapan } \\
& \mathrm{B}=\text { biomassa } \\
& \mathrm{F}=\text { mortalitas penangkapan } \\
& \mathrm{r}=\text { laju pertumbuhan intrinsik } \\
& \mathrm{K}=\text { daya dukung lingkungan }
\end{aligned}
$$

Pendekatan Non-ekuilibrium model surplus produksi pada aplikasi ini diterapkan terhadap data hasil tangkapan dan CPUE dari perikanan pukat cincin di laut Jawa, dengan asumsi bahwa CPUE sebanding dengan kelimpahan. Adapun langkah pertama adalah analisis data CPUE dan hasil tangkapan pada periode 1982-2009, dengan menggunakan pendekatan "trial \& error" terhadap parameter awal rasio biomassa terhadap besarnya biomasa awal (B1/K), estimasi produksi maksimum (MSY), tingkat upaya pada produksi maksimum (Fmsy) dan q (koefisien daya tangkap) untuk memperoleh kombinasi MSY, Fmsy, $\mathrm{q}$ dan $\mathrm{K}$, yang mewakili tren data terkumpul. Output dari model ini adalah estimasi CPUE, mortalitas penangkapan $(F)$ dan biomassa $(B)$, biomassa relatif (B/Bmsy) dan mortalitas penangkapan relatif $(F /$ Fmsy).

\section{HASIL DAN BAHASAN Hasil}

Perkiraan CPUE disesuaikan dengan simulasi distribusi data CPUE observasi menjadi distribusi normal (Gaussian) dan peningkatan stabilitas data sebagai dasar estimasi parameter. Analisis terhadap dua kelompok data serial CPUE ikan layang deles $D$. macrosoma yaitu seluruh data CPUE kurun waktu 1976-2009 dan CPUE setelah produksi tertinggi yang menurun secara bertahap. Berdasarkan kedua pendekatan tersebut dapat diketahui bahwa parameter fungsi produksi surplus dari model logistik (Fmsy, q dan $\mathrm{K}$ ) relatif sama dan Cmsy lebih rendah dari produksi tertinggi dari $D$. macrosoma sebesar 41 ribu ton dan produksi tertinggi total Decapterus spp. sebesar 154 ribu ton. Sementara dari analisis runtun waktu data statistik ikan layang (Decapterus spp) diperoleh nilai Fmsy, q and Cmsy mendekati kelipatan 3 hingga 5 lebih tinggi dari $D$. macrosoma (Tabel 1 ).

Analisis berdasarkan data CPUE D. macrosoma yang disesuaikan membentuk pola sebaran CPUE yang berbeda, yaitu dari seluruh CPUE dianalisis selama 1976-2009 memperlihatkan distribusi normal, sedangkan setelah produksi tertinggi dan CPUE menurun secara bertahap menunjukkan tren yang menurun, karena CPUE observasi pada saat perikanan masih berkembang akan terkoreksi menjadi lebih tinggi (Gambar 1). 
Tabel 1. Parameter fungsi model logistic surplus produksi

Table 1. Parameters of surplus production based on logistic model

\begin{tabular}{lccc}
\hline Parameter & $\begin{array}{l}\text { D.macrosoma } \\
\text { (seluruh data } \\
\text { CPUE) }\end{array}$ & $\begin{array}{c}\text { D.macrosoma (CPUE } \\
\text { setelah produksi } \\
\text { tertinggi) }\end{array}$ & $\begin{array}{c}\text { Decapterus spp. } \\
\text { (CPUE setelah } \\
\text { produksi tertinggi) }\end{array}$ \\
\hline Fmsy & 0.1 & 0,165 & 0,143 \\
K (x1000 ton) & 408 & 225,4 & 1.276 \\
q (x10-6ton) & 0,98 & 2,64 & 8,18 \\
Cmsy (x $\times 1000$ ton) & 22,4 & 18,5 & 109,3 \\
Bmsy (x1000 ton) & 204 & 113 & 638 \\
r & 0,2 & 0,327 & 0,286 \\
\hline
\end{tabular}

Keterangan/Remarks: Cmsy $=K r / 4, B M S Y=K / 2, F M S Y=r / 2$.

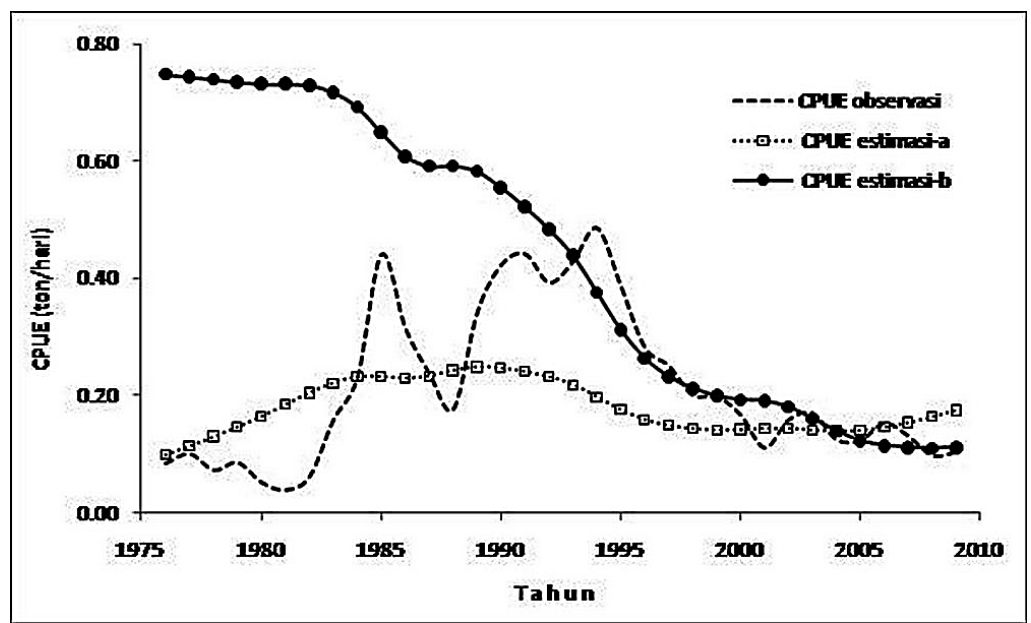

Gambar 1. Tren CPUE yang diamati terhadap prediksi CPUE yang disesuaikan dari $D$. macrosoma selama kurun waktu 1976-2009.

Figure 1. Observed annual trend versus predicted CPUE that adjusted for D. macrosoma during the years of 1976-2009.

Keterangan/remarks:

a) Seluruh data dianalisis / all data CPUE analyzed.

b) CPUE yang disesuaikan setelah produksi tertinggi and menurun bertahap / adjusted CPUE after the highest production and decreased gradually

Dengan menggunakan asumsi dasar bahwa indeks CPUE sebanding kelimpahan ikan maka tren biomassa akan mengikuti pola distribusi CPUE tahunan, sebagaimana yang diterakan pada Gambar 2. Pada Gambar 2, perkiraan biomassa dari pola distribusi CPUE tahunan yang diturunkan berdasarkan perbedaan pendekatan yang diperlihatkan pada Gambar 1. Hasil analisis menunjukkan bahwa penggunaan seluruh data (biomassa estimasi a) memberikan hasil yang tidak realistis pada perkiraan titik awal biomassa pada tahapan tumbuhnya perikanan pada 1980. Sementara tren biomassa dengan pendekatan distribusi CPUE setelah produksi tertinggi dan CPUE menurun secara bertahap mencerminkan titik biomassa awal mendekati nilai $\mathrm{K}$ (biomasa - estimasi b).

Kurva produksi pada Gambar 2, memperlihatkan bahwa besarnya biomassa tahun berjalan secara teoritis tergantung pada besarnya biomassa awal (Bo) dan kondisi lingkungan perairan yang dianggap relatif tetap. Secara umum, kondisi stok dan tingkat pemanfaatkan berdasarkan acuan untuk menentukan pengelolaan (management benchmarks) yang ditetapkan $\mathrm{B} / \mathrm{Bmsy}$ dan $\mathrm{F} / \mathrm{Fmsy}=1$. Plot tahunan mortalitas penangkapan (F/Fmsy) dan biomassa relatif (B/Bmsy) dari seluruh CPUE yang dianalisis selama 1976-2009 menunjukkan posisi tren biomassa relatif berada di bawah $\mathrm{B} / \mathrm{Bmsy}=1$, atau perikanan telah mengalami overfishing sepanjang perikanan masih berkembang (Gambar 3). Plot tahunan F/Fmsy dan B/Bmsy dari data setelah produksi tertinggi dan CPUE menurun secara bertahap menunjukkan tingkat biomassa relatif menurun dan berada pada posisi di bawah F/Fmsy=1 setelah tahun 1994 . Sejalan dengan hal tersebut, biomassa relatif menurun di bawah 1,0 dan stok ikan layang deles telah tertekan di bawah tingkat MSY, dan sejak 1995 upaya penangkapan berada pada status lebih tinggi dari titik acuan optimum Fmsy. 


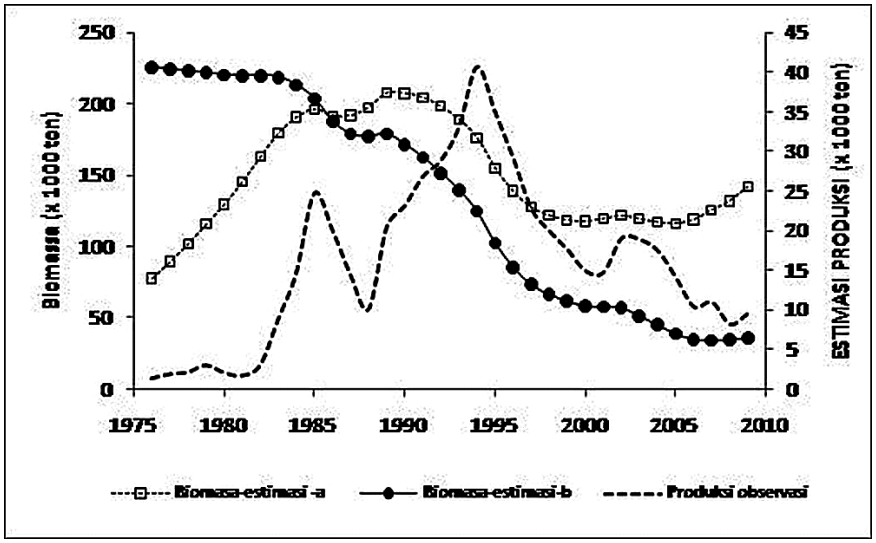

Gambar 2. Tren produksi, estimasi dan rata biomassa dari D. macrosoma selama tahun 1982- 2009. a) CPUE yang disesuaikan seluruh data, b) CPUE yang disesuaikan setelah produksi tertinggi dan CPUE menurun secara bertahap.

Figure 2. Trend of production, estimated average biomass for D. macrosoma during the years 1982 to 2009; a) CPUE adjusted all data; b) CPUE adjusted after the highest production and CPUE decreased gradually.

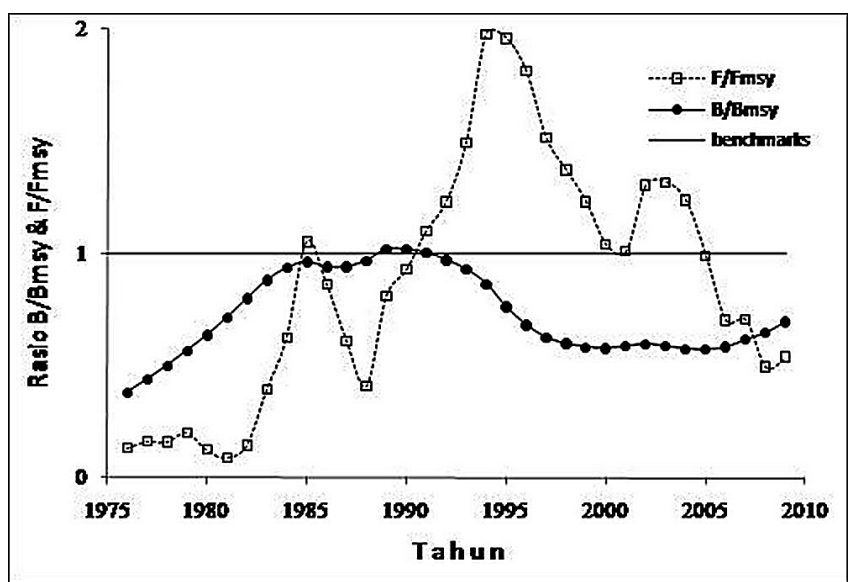

Gambar 3. Tren biomassa dan mortalitas relatif $D$. macrosoma dari data CPUE yang disesuaikan seluruhnya selama 1975-2009.

Figure 3. Trend of relative biomass and fishing mortality of D. macrosoma based on all adjusted CPUE data during 1975-2009.

Keterangan/Remarks: - - - - - ambang batas pengelolaan

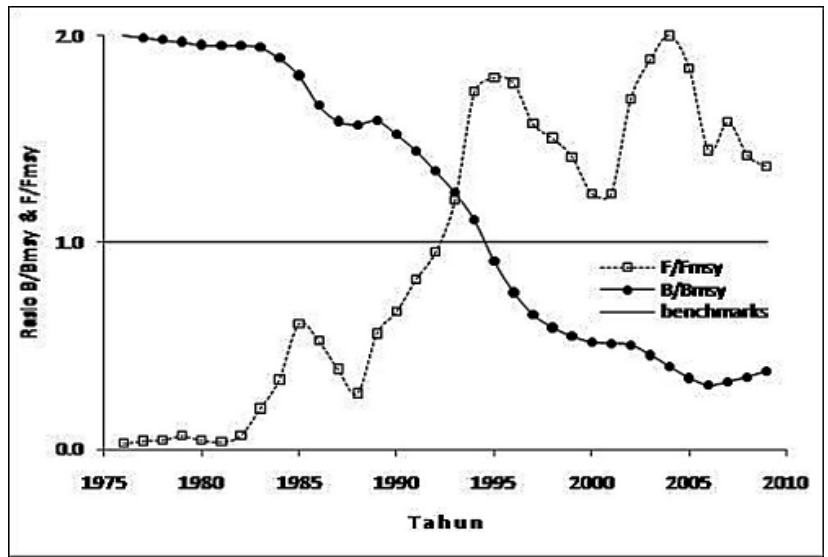

Gambar 4. Tren biomassa dan mortalitas relatif $D$. macrosoma dari data CPUE yang disesuaikan setelah produksi tertinggi selama 1975-2009.

Figure 4. Trend of relative biomass and fishing mortality of D. macrosoma based on adjusted CPUE refers to the highest production during 1975-2009.

Keterangan/Remarks: - - - - : acuan pengelolaan/management benchmarks 
Perkembangan perikanan secara konsisten berhubungan dengan meningkatnya upaya penangkapan dan penurunan CPUE. Perkembangan tersebut dapat dikelompokan menjadi empat tahapan (Gambar 5), yaitu; perikanan tahap tumbuh atau berkembang, eksploitasi penuh, overfishing/overfished, pemulihan/recovery (Restrepo, 2011). Secara rinci setiap peristiwa dapat diterangkan sebagai berikut: pada runtun waktu 1980-1990, sebagian nelayan pukat cincin masih terkonsentrasi di daerah penangkapan tradisional, sejalan dengan investasi kapal baru yang lebih besar dengan bobot 80-100 GT. Pada 1986/1987, operasi penangkapan armada besar tersebut meluas ke bagian timur Laut Jawa dan Selat Makassar. Runtun waktu 1991 - 1995 adalah periode adanya peningkatan efisiensi penangkapan melalui penggunaan cahaya sebagai alat bantu pengumpul ikan menggantikan peranan rumpon yang ditanam, dan sebagian besar taktik penangkapan telah menggunakan lampu sorot dengan sumber cahaya berkekuatan tinggi (>10 Kw) (Atmadja \& Sadhotomo, 1985; Potier \& Sadhotomo, 1995).

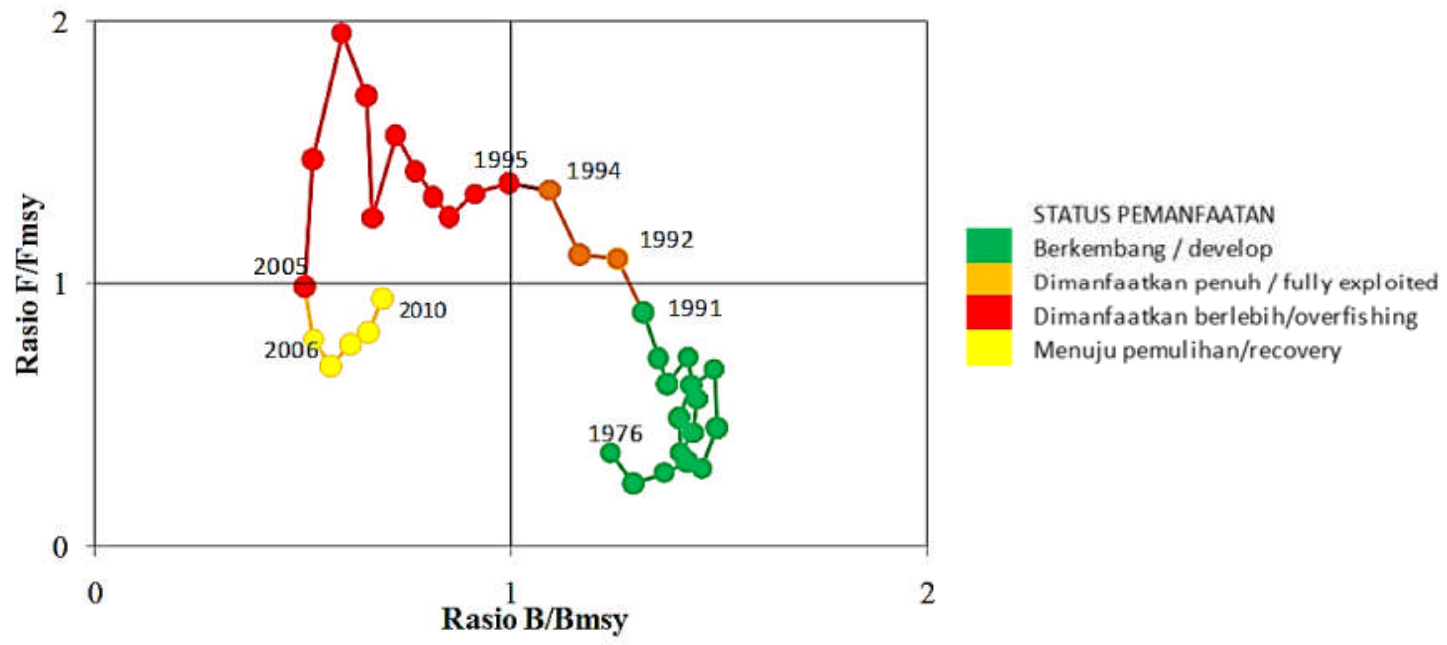

Gambar 5. Plot biomassa (B/Bmsy) dan mortalitas penangkapan (F/Fmsy) yang menggambarkan dinamika status stok ikan layang (Decapterus spp.) dalam empat fase.

Figure 5. Plot of relative biomass (B/Bmsy) and fishing mortality (F/Fmsy) representing the dynamics stock status of scads (Decapterus spp.) within 4 phases.

Keterangan/Remarks: garis B/Bmsy dan F/Fmsy $=1$ acuan pengelolaan

\section{Bahasan}

Penerapan model ASPIC telah digunakan pada evaluasi status perikanan di beberapa negara seperti halnya penentuan hasil tangkapan yang dapat diterima secara biologi (acceptable biological catch) berdasarkan batasan pemanfaatan berlebih di perairan Atlantik Utara (Prager \& Shertzer, 2010); pengkajian stok Redfish (S. mentella and S. fasciatus) di perairan Barat Daya Atlantik (Avila de Melo et al., 2012). Sedangkan Gascoigne (2016) menggunakan model tersebut untuk evaluasi stok perikanan sardine di perairan Maroko yang menghasilkan status lebih pungut terhadap perikanan sardine. Kalhoro et al. (2013) juga melakukan estimasi MSY ikan nomei (Harpodon neherus) di perairan Pakistan menggunakan model ASPIC dan merekomendasikan untuk menurunkan hasil tangkapan perikanan pukat hela di kawasan tersebut. Estimasi status pemanfaatan ikan pelagis kecil di perairan Laut Tengah dilakukan dengan model yang sama dan memberikan hasil perlunya pembatasan pemanfaatan akibat sta- tus stok berada pada kondisi pemanfaatan berlebih (Cardinale et al., 2009b). Pada tataran pengelolaan tingkat regional, (Chassot et al., 2009) telah menggunakan model yang sama pada evaluasi perikanan rawai tuna terhadap spesies tuna mata besar (Thunnus obesus) di perairan Samudra Hindia dan menyimpulkan bahwa dinamika pemanfaatan cenderung mengarah pada kondisi biomassa yang terus menurun akibat peningkatan laju kematian penangkapan yang semakin tinggi.

Estimasi status stok ikan layang ditentukan dengan menggunakan nilai $r$ dan $\mathrm{K}$ pada model produksi non-equilibrium berasosiasi dengan estimasi CPUE yang mengikuti osilasi perkembangan produksi daripada laju pertumbuhan populasi yang sebenarnya. Pertumbuhan organisme adalah hasil proses sangat rumit yang berkaitan dengan faktor abiotik dan biotik lingkungan, interaksi spesies (pemangsaan dan kompetisi), dan perubahan struktur komunitas (Krebs, 1985). Laju pertumbuhan alami stok tergantung pada besaran stok ikan dan parameter lingkungan. Secara 
teoritis, hubungan antara indeks biomassa relatif, pertumbuhan intrinsic suatu populasi ( $r$ ) dan kemampun tangkap (q) akan berubah-ubah sesuai dengan tersedianya kelimpahan ikan yang dapat dimanfaatkan. Apabila kondisi lingkungan termasuk hubungan mangsa dan pemangsa relatif stabil, maka pengaruh terhadap stok diharapkan relatif stabil sehingga dampak penangkapan merupakan faktor utama terhadap perubahan kelimpahannya (Shelton \& Mangel, 2011).

Model surplus produksi sejauh ini dapat memberikan gambaran umum tentang status stok ikan karena model tersebut tidak memasukkan karekteristik biologis dan lingkungan (Quinn \& Deriso, 1999), sehingga pada saat tidak tersedianya besarnya biomassa, maka untuk menentukannya diasumsikan bahwa tingkat tangkapan (C) sebanding dengan ukuran stok dan upaya penangkapan. Dalam konteks estimasi parameter untuk model biomassa dinamis, data CPUE digunakan harus dilakukan berdasarkan runtutan data hasil tangkapan dan upaya penangkapan pada kisaran waktu yang relatif panjang (Hilborn \& Walters, 1992).

Hilborn (2002) menyatakan masalah yang timbul dari titik acuan MSY tersebut, adalah ketidakpastian estimasi biomassa saat ini dan biomassa pada saat belum dimanfaatkan (K). Pendugaan besaran biomassa $(\mathrm{K})$ tersebut tergantung pada teknik ekstrapolasi yang digunakan. Apabila data tersedia sejak awal perikanan, maka penggunaan asumsi $B_{0}$ = K lebih dapat diterima, namun upaya penelusuran data awal perikanan tidak memberikan hasil termasuk perubahan lingkungannya. Penelitian di perairan yang berbeda menunjukkan bahwa perkembangan eksploitasi sumber daya ikan umumnya bersifat tidak stabil dan berfluktuasi secara acak (Hilborn \& Walters, 1992).

Suatu kenyataan yang dihadapi bahwa sediaan stok ikan pelagis kecil di perairan Laut Jawa sudah berada pada status kelebihan kapasitas penangkapan dan kejenuhan bagi usaha perikanan. Fenomena ini digambarkan oleh bertambahnya hari laut pada satu trip serta sebagian armada melakukan perubahan taktik dan strategi pemanfaatan menuju perairan oseanik (Atmadja et al., 2012). Setiap fenomena tersebut berkaitan langsung dengan perkembangan taktik dan strategi pemanfaatan perikanan pukat cincin di Laut Jawa dan sekitarnya. Selama tahapan ekspansi, peningkatan total upaya penangkapan bertepatan dengan peningkatan secara terus menerus ketrampilan nelayan dan pengembangan teknologi penangkapannya. Pengembangan taktik penangkapan kerapkali melibatkan inovasi teknologi alat bantu penangkapan dengan kombinasi penggunaan cahaya dan rumpon, GPS serta pemerum gema ikan (fish finder) sebagai sarana pengumpul ikan untuk meningkatkan efisiensi penangkapan. Pembagian tahapan perkembangan perikanan pukat cincin di Laut Jawa telah dibahas dalam kajian sebelumnya (Potier, 1998; Atmadja, 2008). Perubahan besar terjadi pada kurun waktu 1985 yang dicirikan oleh perubahan taktik penangkapan dengan bantuan fish finder dan cahaya yang diikuti perluasan daerah penangkapan dan seluruh kawasan laut Jawa telah dieksploitasi dan sebagian besar armada pukat cincin berukuran besar (> 30GT) meluaskan daerah penangkapan ke arah bagian Timur Laut Jawa dan bagian Selatan Laut Cina Selatan. Perluasan ini berkaitan dengan investasi kapal baru yang lebih besar dengan ukuran bobot 80 100 GT. (Atmadja \& Sadhotomo, 1985; Potier \& Sadhotomo, 1995).

Penyesuaian terhadap kebijakan pemerintah tentang penyesuaian harga bahan bakar minyak (BBM) pada 1 Oktober 2005 dengan rata-rata kenaikan melebihi $100 \%$ telah memberikan dampak terhadap aktivitas kapal pukat cincin, sebagaimana yang terjadi pada kapal pukat cincin dengan bobot >80GT yang berpangkalan di Pekalongan. Aktivitas kapal tahunan menurun $50-70 \%$ dibandingkan tahun sebelumnya. Armada tidak aktif, hanya tambat di pelabuhan karena ketidak seimbangan perolehan hasil tangkapan dan biaya operasi (Atmadja, 2008). Bagaimanapun juga, pada status stok ikan pemanfaatan berlebih, terjadinya penurunan aktivitas kapal pukat cincin setelah pengurangan subsidi BBM tidak semata-mata dipengaruhi oleh kenaikan biaya operasional, tetapi sangat terkait dengan semakin menipisnya hasil tangkapan sebagai akibat menipisnya stok ikan yang tersedia.

Pada kasus sumberdaya ikan layang dan perikanan pukat cincin, penetapan JTB (jumlah tangkapan yang dibolehkan) yang mengacu pada MSY berdasarkan produksi tertinggi dan penurunan CPUE secara bertahap tidak lagi relevan. Sebaliknya, pengelolaan perikanan berbasis pengendalian input harus dilakukan dengan cara membatasi upaya penangkapan untuk mencapai mortalitas penangkapan lebih rendah dari nilai Fmsy, pendekatan pola eksploitasi yang lebih konservatif sangat diperlukan untuk memulihkan kembali status stok pada tingkat biomassa optimal.

Estimasi MSY berdasarkan data 1969 - 2009 memberikan volume optimum yang bersifat dinamis, berdasarkan data statistik perikanan tangkap 19691976, estimasi hasil tangkapan lestari (MSY) sebesar 
76.000 ton (Sudjastani, 1978), pada 1976-1982 dengan estimasi luas perairan $91.000 \mathrm{~km}^{2}$ memberikan nilai hasil tangkapan optimum sebesar 79.000-81.000 ton tahun $^{-1}$ dengan upaya hari laut pada nilai 62.000-84.000 tahun $^{-1}$. Selanjutnya, pada tahun 1983-1984 dengan perubahan luas daerah penangkapan sebesar 179.000 $\mathrm{km}^{2}$ memberikan nilai hasil tangkapan optimum sebesar 155.000-159.000 ton tahun ${ }^{-1}$ dengan upaya hari laut pada nilai 123.000-165.000 tahun-1, kemudian pada tahun $1985-1986$ (luas $202.000 \mathrm{~km}^{2}$ ) nilai hasil tangkapan optimum sebesar 175.000 180.000 ton tahun $^{-1}$ dengan upaya hari laut pada nilai 138.000-187.000 hari tahun ${ }^{-1}$ (Nurhakim et al., 1995). Runtutan perubahan estimasi produksi optimum sejalan dengan ekspansi daerah penangkapan dengan luasan kelipatan 2. Potensi produksi tahunan di WPP 712 diperbarui melalui estimasi pada tahun 2011 dengan volume sumberdaya ikan pelagis kecil yang dapat dimanfaatkan sebesar 380.000 ton (KepMen 45/Men/2011) kemudian diperbarui lagi melalui Keputusan Menteri No, 47/KepMen-KP/2016 sebesar 365.000 ton.

Evolusi status sumber daya sejak tahun 1976 sampai dengan 2010 lebih nyata digambarkan pada penelitian ini. Dinamika status biomasa secara historis memperlihatkan bahwa pada runtun waktu 1980-1991 kondisi stok ikan menurun akibat terlalu intensifnya pemanfaatan. Penurunan tersebut menimbulkan terjadinya ketidakseimbangan penangkapan terhadap beberapa stok ikan di dalam populasi ikan layang secara keseluruhan, sehingga komunitas ikan pelagis berusaha mencapai keseimbangan pada tingkat kelimpahan yang lebih rendah. Fenomena ini menggambarkan aktivitas perikanan pukat cincin semi industri telah mencapai titik jenuh di hampir seluruh kawasan Laut Jawa. Stok ikan pelagis yang tersisa tidak mampu lagi mendukung jumlah armada perikanan yang terlanjur masuk ke dalam usaha perikanan.

Pada runtun waktu 2006 - 2009 merupakan periode pemulihan stok (recovery) karena sebagian armada pukat cincin yang beroperasi ke luar dari perikanan, sehingga penurunan upaya penangkapan tersebut memungkinan biomassa untuk meningkat kembali. Namun kenyataan memperlihatkan bahwa eksodus armada berukuran besar beroperasi di luar laut Jawa diikuti peningkatan rasio mortalitas penangkapan yang diduga akibat tidak terkendalinya perkembangan armada pukat cincin yang berukuran kurang dari 30 GT. Pada 2009 jumlah kapal aktif di Pekalongan hanya tersisa sekitar $30 \%$ dibandingkan pada 2005, sedangkan bila dibandingkan dengan jumlah tertinggi yang terjadi pada 1995, nilai berada pada kisaran $18-19 \%$. Secara operasional, turunnya biomassa yang dicirikan oleh turunnya hasil tangkapan per trip ditanggapi dengan rasionalisasi upaya penangkapan oleh pengusaha/nelayan dengan cara mendorong pengusaha melakukan relokasi usaha perikanannya secara mandiri ke perairan sekitar Laut Natuna dan Selat Makassar. Sementara pengusaha tidak merelokasi usahanya, melakukan diversifikasi usaha dengan mengganti perangkat penangkapannya dengan mengalihkan sebagian kapal penangkap menjadi kapal penangkap cumi-cumi atau berganti alat tangkap dengan menggunakan jaring cantrang (Atmadja, 2008).

Hal ini mengisyaratkan bahwa MSY bukan indikator mutlak untuk pengelolaan, karena hasil tangkapan berdasarkan atas statistik resmi tidak mencerminkan hasil tangkapan yang sebenarnya akibat sistem perikanan masih pada tataran ekspansi. Perbedaan ini diduga terjadi akibat terjadinya hasil tangkapan yang tidak terpantau sehubungan tempat pendaratan ikan yang tersebar luas dan mempunyai karakteristik berbeda atau memang tidak dipantau karena hambatan logistik. Oleh karena itu, dalam penelitian ini kondisi dan status stok ikan layang pada 2010 yang digambarkan berdasarkan tren biomassa dan mortalitas penangkapan relatif (F/Fmsy) dan biomassa relatif (B/Bmsy) berada pada status biomassa yang tersedia dibawah kapasitas pemanfaatan optimal walaupun mortalitas pemanfaatan yang sedang berjalan $(F)$ pada status lebih rendah dari Fmsy.

Proses pemulihan biomassa masih memerlukan waktu dan ketegasan tindakan pengendalian upaya pemanfaatan yang sedang berjalan. Berbagai teori pembatasan input untuk pemulihan sumberdaya umumnya lebih dapat diterima oleh pelaku usaha, salah satu yang dapat dilakukan adalah pembatasan investasi kapal baru serta kapal yang telah berada pada efisiensi teknis dan kapasitas penangkapan yang rendah agar tidak dilakukan pembaruan izin penggantian kapal termasuk armada yang berbobot < 30 GT dengan kewenangan pemerintah daerah. Penguatan kawasan perlindungan laut, semakin dirasakan penting untuk diterapkan terutama kawasan perairan karang yang berada di sekitar kepulauan seribu, Karimunjawa, Bawean, Matasiri dan Masalembu diduga merupakan kawasan yang berasosiasi dengan sebagian daur hidup kelompok jenis ikan pelagis kecil. Beberapa peran kawasan perlindungan laut telah diterapkan di beberapa negara dan memberikan peluang untuk pemulihan ikan pelagis yang terjadi di perairan laut Tengah (Faozai et al., 2012); 
Peningkatan kesadaran masyarakat pelaku usaha untuk mengetahui dan mempertahankan titik acuan pengelolaan perikanan dengan pada tingkat biomasa optimum akan sangat berperan dalam mendukung kebijakan keberlanjutan sumberdaya ikan pelagis kecil di WPPRI-712.

\section{KESIMPULAN}

Penerapan model ASPIC (a surplus production model incorporating covariates) memperjelas status pemanfaatan dan dinamika stok sumber daya ikan berdasarkan tingkat rasio biomassa (Bmsy) dan mortalitas penangkapan (Fmsy). Fenomena lebih tangkap yang terjadi tidak memunculkan multitafsir, sehingga peluang pengambilan keputusan dapat dilakukan sebelum runtuhnya aktivitas perikanan yang sedang berjalan. Penerapan model berdasarkan runtutan waktu pemanfaatan pada 1976 - 2009, memberikan indikasi bahwa tren biomassa terpetakan dengan kecenderungan pergeseran terus menurun sejak 1992-1993. Tingkat eksploitasi telah melampaui batas kewajaran (Fmsy) dan status biomassa melebihi kapasitas maksimum biomassa yang dapat dimanfaatkan (Bmsy). Rendahnya pemahaman terhadap pengendalian input melalui pengendalian investasi kapal baru menyebabkan status pemanfaatan semakin mengarah pada kondisi lebih tangkap. Hal ini mengakibatkan rendahnya kemampuan pulih biomassa serta semakin menipisnya sediaan induk untuk menjamin kelangsungan populasi bagi pemanfaatannya. Penetapan jumlah tangkapan yang diperbolehkan (JTB) berlandaskan pada nilai MSY setelah produksi tertinggi dan penurunan CPUE secara bertahap akan lebih terkelola dengan mempertimbangkan pengendalian upaya penangkapan baik kapasitas maupun taktik penangkapannya. Proses pengambilan keputusan harus lebih rasional untuk membatasi mortalitas akibat penangkapan berada pada tingkat MSY (Fmsy). Upaya pengendalian mortalitas penangkapan melalui pembatasan investasi kapal baru akan memberikan kondisi perikanan yang lebih konservatif sesuai pola eksploitasi yang seharusnya. Pengendalian ditujukan untuk memberikan peluang pembangunan kembali stok pada tingkat biomassa optimal dan mortalitas penangkapan pada kondisi pemanfaatan optimum.

\section{DAFTAR PUSTAKA}

Avila de Melo, A.M., Alpoim, R., \& Troncoso, D.G. (2012). An ASPIC Based Assessment of Redfish (S. mentella and S. fasciatus) in NAFO Divisions 3LN (can a surplus production model cope with bumpy survey data?). Scientific council meeting. NAFO SCR Doc, 12/032. 63p.

Atmadja, S.B., Nugroho, D., \& Suryanto. (2012). Adaptasi perikanan pukat cincin di Laut Jawa dan implikasinya terhadap pengelolaan. J.Lit. Perikan.Ind. 6(2),105-111.

Atmadja, S.B., \& Sadhotomo, B. (1985). Aspek operasional pukat cincin di laut Jawa. Lap.Pen. Per. Laut. 32, 65-71.

Atmadja, S.B. (1999). Variasi geografis hasil tangkapan ikan layang (Decapterus spp.) di perairan bagian selatan Paparan Sunda. J.Lit. Perikan Ind. 5 (3), 63 -71.

Atmadja, S.B. (2008). Sumberdaya Ikan Pelagis Kecil: Dinamika Perikanan Pukat Cincin di laut Jawa dan Sekitarnya (p. 98). Balai Riset Perikanan Laut.

Botsford, L.W., Holland, M.D. Field, J.C., \& Hastings, A, (2014). Cohort resonance: a significant component of fluctuations in recruitment, egg production, and catch of fished populations. ICES Jour. of Mar. Sci., 71(8), 2158-2170.

Cardinale, M., Nugroho, D., \& Hernroth, L. (2009a). Reconstructing historical trends of small pelagic fish in the Java Sea using standardized commercial trip based catch per unit of effort. Fish. Res., 99, 151-158.

Cardinale, M., Rätz, H.J., \& Cheilari, A. (2009b). Report of the SGMED-09-02 Working Group on the Mediterranean Part I. Scientific, Technical and Economic Committee for Fisheries (STECF). EUJoint Research Centre. Institute for the Protection and Secutity of the Citizen. 850 p.

Chassot, E., Nishida, T., \& Fonteneau, A. (2009). Application of surplus production models to the Indian Ocean Bigeye (Thunnus obesus) tuna fishery. IOTC-2009-WPTT-04. 22 p.

Direktorat Jenderal Perikanan (DJP) (1980-2000) Statistik perikanan Indonesia menurut propinsi Departemen Pertanian, Direktorat Jenderal Perikanan, Jakarta.

Direktorat Jenderal Perikanan Tangkap (DJPT) (20012015). Statistik Perikanan Tangkap Indonesia menurut propinsi. Kementerian Kelautan dan Perikanan. 
Fouzai, N., M. Coll, I. Palomera, A. Santojanni, E. Arneri, V. Christensen. (2012). Fishing management scenarios to rebuild exploited resources and ecosystems of the Northern-Central Adriatic (Mediterranean Sea). Journal of Marine Systems 102104:39-51.

Gascoigne, J. (2016). Moroccan sardine fishery: assessment in relation to the MSC standard February 2016, Moroccan Sardine FIP, 28pp. http:// fisheryimprovement projects.org/wp-content/uploads/Sustainability-evaluation-Fev2016.pdf (downloaded 10 February 2017 22:00 pm).

Hilborn, R. (2002). The dark side of reference points. Bull. Mar. Sci. 70, 403-408.

Hilborn, R., \& Walters, C.J. (1992). Quantitative Fisheries Stock Assessment: Choice, Dynamics and Uncertainty. Chapman and Hall. New York, London. 570 p.

Kalhoro, M.A., Liu, Q. Memon, K.H. Chang, M.S., \& Jatt, A.N. (2013). Estimation of Maximum Sustainable Yield of Bombay Duck, Harpodon nehereus Fishery in Pakistan Using the CEDA and ASPIC Packages. Pakistan J. Zool. 45(6), 17571754.

Krebs, C. J. (1985). Ecology, the experimental analysis of distribution and abundance (p. 800). Harper \& Row, Publishers, New York.

Nugroho, D. (2006). Kondisi trend biomassa ikan layang (Decapterus spp.) di Laut Jawa dan sekitarnya. J.Lit.Perikan.Ind. 12 (3), 167-173.

Nurhakim, S., Sadhotomo, B., \& Potier, M. (1995). Composite model on small pelagic resources. Di dalam: Potier and S. Nurhakim, editor: Biodynex. Seminar Biology, Dynamics and Exploitation of small pelagic in Java Sea. Jakarta, 21 - 25 March 1994. EEC/ AARD/ORSTOM. 145-153.

Prager, M.H. (1994). A suite of extension to a nonequilibrium surplus-production model. Fish. Bull. US; 92:374-389.

Prager, M.H., \& Shertzer, K.W. (2010). Deriving acceptable biological catch from the overfishing limit: Implications for assessment models. North Am. J. of Fish. Mana. 30, 289-294.
Potier, M. (1998). Pêcherie de layang et senneurs semi industriels Javanais: Perspective historique et approche système. Phd Thesis, Université de Montpellier II, 280 p.

Potier, M., \& Sadhotomo, B. (1995). Exploitation of the large and medium seiners fisheries. In : Potier M. \& Nurhakim, S. (Eds.), Biology, Dynamic and Exploitation (BIODYNEX). AARD/ORSTOM, 195214.

Quinn, II T.J., \& Deriso, R.B. (1999). Quantitative fish dynamics. Oxford University Press, New York, USA.

Quetglas, A., Ordines, F. Hidalgo, M. Monserrat, S. Ruiz, S. Amores, A. Moranta, J., \& Massutí, E. (2013). Synchronous combined effects of fishing and climate within a demersal community. ICES J. Mar. Sci., 70, 319-328.

Restrepo, V. (2011). Stock Assessment 101: Current Practice for Tuna Stocks. http:// www.trimarinegroup.com/resources/papers/ Stock20Assessments2010.pdf

Schaefer, M.B. (1954). Some aspects of the dynamic of population important to management of the commercial marine fisheries. Bull. Inter-Am. Trop. Tuna Comm. 1, 25-26.

Schaefer, M.B. (1957). A study of the dynamics of the fishery for yellowfin tuna in the eastern tropical Pacific Ocean. Bull. Inter-Am. Trop. Tuna Comm 2: 247-285.

Shelton, A.O., \& Mangel, M. (2011). Fluctuations of fish populations and the magnifying effects of fishing. PNAS, 108(17), 7075-7080.

Sudjastani, T. (1978). Perhitungan besarnya stock sumber-sumber perikanan di Laut Jawa berdasarkan data statistik perikanan daerah. Simposium Modernisasi Perikanan Rakyat. Balai Penelitian Perikanan Laut, Jakarta. 20 p. 